\title{
Outright Cash Purchase of Capital Assets and Enterprise Profitability in Nigeria: A Reflection on the Construction Industry
}

\author{
Loveday A. Nwanyanwu ${ }^{1}$ \\ ${ }^{1}$ Department of Accountancy, Rivers State University of Science and Technology, Port Harcourt, Federal Republic of \\ Nigeria. \\ Correspondence: Loveday A. Nwanyanwu, Department of Accountancy, Rivers State University of Science and \\ Technology, Port Harcourt, Federal Republic of Nigeria.
}

Received: May 14, 2015

Accepted: May 21, 2015

Available online: June 12, 2015

doi:10.11114/afa.v1i2.881

URL: http://dx.doi.org/10.11114/afa.v1i2.881

\begin{abstract}
This paper examines the influence of capital assets acquired outrightly by cash on enterprise profitability from the perspective of construction companies. Data were obtained by means of questionnaire. Analyses were performed using descriptive statistics and Pearson's product moment coefficient of correlation. Results of descriptive statistics indicate $61.11 \%$ preference for acquisition of capital assets by outright cash purchase. Correlation analysis reveals a statistically significant moderate positive relationship between capital assets acquired out rightly through cash payment and net profit. Own capital assets acquired by outright cash purchase improves net profit performance of construction companies. Companies in the construction sector should aim at investing in capital assets through outright cash purchase instead of hiring or leasing.
\end{abstract}

Keywords: Outright cash purchase, profitability, capital assets, construction, Nigeria.

\section{Introduction}

Options for investing in capital assets vary from one organisation to another depending on fund availability and the interest to own a capital asset. Investing in capital assets could be by leasing, credit purchase, hire purchase or outright cash purchase (Alexander and Britton, 1999). Leasing may or may not confer ownership of the property to the purchaser depending on the type of lease. Whereas an operating lease gives the lessee the right to benefit from the services of the capital asset, a finance lease confers on the lessee the option to own the asset at the end of the lease term. Credit purchase as well as cash purchases transfers ownership immediately on acquisition. In the case of credit purchase, the seller may resort to legal action to obtain complete payment in the event of the purchaser's inability to pay fully for the property. Hire purchase only transfers ownership of the capital assets to the purchaser on payment of the last installment contained in the agreement; otherwise, the owner repossesses the asset.

Wood and Ross (2006: 676-695) reported the importance of environmental social controls (ESCs) to Australian financial managers in making capital investment decisions. A decision-making experiment performed indicate $42 \%$ of managers are responsive to stakeholder opinion, $26 \%$ are responsive to subsidisation, regulatory cost (22\%) while mandatory disclosure is $10 \%$. Findings indicate ESC interaction effects are limited; as a result, co-ordination of ESC policy is not a primary concern in capital investment. High degrees of managerial self-insight suggest policy changes would be enhanced by close consultations with the managers concerned.

Kehinde and Mosaku (2006: 634-644) found that the assets structure of building construction contractors comprise of fixed assets being less than half of the total assets, which imply that a greater proportion of the total assets is current assets (held mainly as account receivables that sometimes may not be available within one year). They noted that there is generally a low investment in fixed assets from earnings over the years. As a result, the assets structure of these firms could impact on their ability to compete successfully on some project types, especially where hiring options for plant and equipment are unavailable.

These studies did not investigate the options for investing in capital assets and their influence on profitability. This paper attempts to close this gap by examining the cash purchase option of capital assets investment and its influence on enterprise profitability in Nigeria, an emerging economy, drawing evidence from the construction industry. The next sections will discuss literature review, methodology, data presentation and analysis. Others are discussion of findings, 
conclusion and recommendation.

\section{Literature Review}

\subsection{Outright Cash Purchase}

Outright cash purchase is one of the practices adopted for investing in capital assets (Alexander and Britton, 1999). This approach presupposes availability of sufficient fund (cash) for capital expenditure. Unlike leasing and hire purchase, this alternative transfers ownership of the asset immediately to the investor. The introduction of various economic programmes over the years by the government such as structural adjustment programme (SAP), austerity measure and the devaluation of the naira coupled with high lending rates make this system of capital asset acquisition burdensome on organizations especially, construction companies that depend more on heavy duty machinery for their activities. According to Yeo and Ning (2006: 123-34), in managing construction equipment, contractors are invariably plagued with several difficulties such as huge capital investment in the acquisition phase, which usually constitutes a major financial burden. They noted that procurement of major construction equipment represents as high as $36 \%$ of the total construction project cost.

The foregoing notwithstanding, it is believed that smart acquisition practices fuel company success (Mitchell, 1998). In practice, capital conservation is a major factor for most organizations in considering to buy, lease or rent on an installment plan (Sutton, 2003: 9). However, most organizations irrespective of size prefer a purchasing strategy than other options (Stewart, 2002: 44).

The decision to invest in capital assets is influenced by factors such as lower price, availability of spare parts, improved technology, versatility in usage, availability of cash, lower interest rate (if financed by borrowing), high residual value; etc. Price reduction as a factor in purchasing is mostly applicable in competitive conditions where dealers offer varying discount rates. Equipment dealers / manufactures with high discount rates sale more equipment than those with low discount rates. Spare parts availability is an important determinant of capital asset investment decision. This factor increases a capital asset's life cycle as well as reduces maintenance cost. Improvements in technology possess the capacity to increase productivity of a particular capital asset; hence it can increase the demand for the purchase of that asset. Versatility in usage which is the ability to be used in more than one work situation is capable of propelling a company's decision to invest in a capital asset. An example is a low bed lorry which can be used to transport caterpillars from one construction site to another as well as transport heavy steel pipes for culverts and bridges. An overriding factor in physical capital investment is cash availability, this is essential as a company with low capital accumulation may not opt for outright purchase of capital assets.

Outright cash purchase of capital assets could be grouped into six (6) significant stages based on equipment life cycle. They are acquisition, measurement, operation, maintenance, depreciation and disposal. Tavakoli, Taye and Erktin (1989: 317-329), Hinze and Ashton (1979:225-237), Schexnayder and Hancher (1981: 619-626); identify forty equipment acquisition practices; 27 associated with the decision to purchase or buy are disclosed in table 1 .

Table 1. Equipment acquisition practices:

1. Purchase equipment outright by cash,

2. Purchase equipment by financing,

3. Purchase equipment in used condition,

4. Purchase equipment in new condition,

5. Purchase equipment based on personal judgments,

6. Purchase equipment based on current and future workload,

7. Purchase equipment based on internal rate of return (IRR) of investment,

8. Purchase equipment based on life cycle cost (LCC) of equipment,

9. Purchase equipment based on company financial status,

10. Purchase equipment based on discount or special orders from dealers,

11. Make decision on acquiring or disposing equipment by president/CEO,

12. Make decision on acquiring or disposing equipment by board of directors,

13. Make decision on acquiring or disposing equipment by equipment managers,

14. Make decision on acquiring or disposing equipment by project managers,

15. Purchase equipment based on brand popularity and spares parts availability, 
16. Purchase equipment based on functions and its usage,

17. Purchase the same brand that is being used regularly,

18. Purchase equipment from familiar dealers,

19. Purchase equipment based on its price,

20. Buy new or used machine based on budget availability,

21. Buy used machines because of cheaper price but still in good condition,

22. Buy new machines because of a need in functions and advanced technology,

23. Buy used machines only the ones that do not have complicated systems,

24. Buy new machines only the ones that render expensive repair costs once failure,

25. Buy used machines only the ones that do not have high repair cost once failure,

26. Buy new machines only the one that are frequently utilized for a long time,

27. Buy used machines only the ones that are not frequently utilized.

Source: Hinze and Ashton (1979), Schexnayder and Hancher (1981), Tavakoli et al (1989).

\subsection{Profitability}

Profitability is the ability of an enterprise to earn income in excess of its operating expenses utilizing its resources. It is measured using various factors e.g. turnover, earnings per share, return on capital employed etc, (R. Libby, P. A. Libby and Short, 2001). A popularly used measure of profitability is net profit (Nwanyanwu, 2013: 453) which is the excess of income over expenses incurred within a given accounting period. This paper measures profitability in terms of net profit.

\section{Methodology}

This study adopts a survey approach. Data were collected by means of questionnaire drawn on a five - point scale. The explanatory variable, outright cash purchase, has three questions while the response variable, enterprise profitability, measured in terms of net profit also has three questions. For the explanatory variable, respondents were requested to agree or disagree as to whether their organisations acquire capital assets through outright cash purchase and whether such an approach easily confers ownership of capital assets to their organisations. In addition, they were also requested to respond as to whether such capital assets can easily be made available for construction activities/operation without delay. These sets of questionnaire range from "strongly disagree to "strongly agree".

In respect of the response variable, respondents were requested to rate the performance of their organisations in terms of net profit and turnover (revenue) ranging from "poor" to "outstanding". Also, they were required to rate the level of maintenance cost for newly purchased capital assets from "very low" to "very high".

The population of the study was six unquoted construction companies in the medium and small enterprises sector obtained through a pilot study. The number of companies in the construction sector is usually small when compared to other service providers because of the huge amount of capital required to invest in plant and machinery to meet consumer requirements. In addition, the risk associated with delayed payments common in the industry is also contributory. These six companies were sampled, representing $100 \%$ of the population. To provide a direction for the work, the following hypothesis was formulated:

Outright cash purchase of capital assets has no significant relationship with net profit performance of construction companies.

\section{Data Presentation and Analysis}

Seventy two (72) sets of questionnaire were distributed. Sixty two (62) were returned while fifty four (54) representing a response rate of $75 \%$ were selected for analysis.

\subsection{Univariate Analysis}

\section{Frequency of Responses}

Table 2 presents the frequency table indicating the responses to the questionnaire on the variables studied. Eight respondents strongly disagree that their organisations always purchase capital assets outrightly by cash. Whereas twenty five respondents representing $46.3 \%$ of the valid number of questionnaire analysed agree that their organizations acquire capital assets through outright cash purchase, thirteen are not in agreement. In total, thirty three, accounting for approximately $61.11 \%$ consent that their organizations acquire capital assets by cash purchase, while $38.89 \%$ which is 21 respondents disagreed. On the other hand, the entire 54 respondents maintain that capital assets acquired through 
outright cash purchase confer immediate ownership to investors. From the scale, thirty (30) which is $55.6 \%$ strongly agreed while twenty four (24) representing $44.4 \%$ agreed.

Prompt availability of equipment for operation is considered an important factor in the construction industry. 25 respondents representing $46.3 \%$ and 21 respondents representing $38.9 \%$ agree as well as strongly agree to the possibility of this fact when capital assets are acquired outrightly by cash. Twenty eight (28) respondents gave a "fair" score of 2 in the rating scale with respect to net profit performance of the companies sampled. This notwithstanding, sixteen (16) respondents indicate that net profit performance is "good" while ten (10) representing $18.5 \%$ are of the opinion that net profit performance is "very good". From the views expressed by the respondents, net profit performance of the companies is slightly above average. Previous reports provide supportive evidence. According to Gianotti (2003:6), the prospects of construction companies in Nigeria in terms of profitability performance have not been encouraging. The effects of stiff competition, high cost of labour and materials as a consequence of high level of inflation are contributory. Federal and State governments restructuring policies and funding attitudes resulting into payment delays, construction stoppages as well as outright abandonments negatively impact on profit margins. From the views of Chan, Tam and Cheung (2005:112), most contractors in Hong Kong are suffering from business reduction and profitability deterioration. Some have been struggling very hard to retain their financial performance. The deteriorating financial performance of most contractors in 2001/02 had signaled that it is time to review the micro -economic situation of the construction market.

In terms of turnover (revenue) performance, 26 respondents (48.1\%) rate the companies "very good" while 4 respondents (7.4\%) rated them "outstanding". However, in the eyes of 9 respondents, turnover performance is "fair" while from the perspectives of 15 which is $27.8 \%$, it is "good". These ratings are better than those of net profit. This is understandable because many factors including some uncontrollable overheads e.g. bank charges impact the computation of net profit. Maintenance cost is a very important issue in the decision to invest in capital assets. For new capital assets acquired through outright cash purchase, it is very low from $23(42.6 \%)$ respondents, low from $22(40.7 \%)$ respondents and average from $9(16.7 \%)$ respondents respectively. Ratings may produce the opposite for fairly used capital assets. As reported by Prasertrungruang and Hadikusumo (2007:228), maintenance of equipment is essential to contractor's profitability because it not only extends the useful life of the equipment but also controls the machine availability at a minimum cost.

Table 2. Frequency Table

\begin{tabular}{|c|c|c|c|c|}
\hline Cash purchase of capital Asset & Scale & Frequency & $\%$ & Cumulative \% \\
\hline \multirow[t]{4}{*}{ Valid } & 1 & 8 & 14.8 & 14.8 \\
\hline & 2 & 13 & 24.1 & 38.9 \\
\hline & 4 & 25 & 46.3 & 85.2 \\
\hline & 5 & 8 & 14.8 & 100.0 \\
\hline Capital Asset Ownership & 4 & 24 & 44.4 & 44.4 \\
\hline Valid & 5 & 30 & 55.6 & 100.0 \\
\hline \multirow{3}{*}{$\begin{array}{c}\text { Avalable for company operation } \\
\text { Valid }\end{array}$} & 2 & 8 & 14.8 & 14.8 \\
\hline & 4 & 25 & 46.3 & 61.1 \\
\hline & 5 & 21 & 38.9 & 100.0 \\
\hline \multirow[b]{2}{*}{ Net profit performance } & 2 & 28 & 51.9 & 51.9 \\
\hline & 3 & 16 & 29.6 & 81.5 \\
\hline Valid & 4 & 10 & 18.5 & 100.0 \\
\hline \multirow{4}{*}{$\begin{array}{l}\text { Turnover performance } \\
\text { Valid }\end{array}$} & 2 & 9 & 16.7 & 16.7 \\
\hline & 3 & 15 & 27.8 & 44.4 \\
\hline & 4 & 26 & 48.1 & 92.6 \\
\hline & 5 & 4 & 7.4 & 100.0 \\
\hline \multirow[t]{3}{*}{ Maintenance cost } & 3 & 9 & 16.7 & 16.7 \\
\hline & 4 & 22 & 40.7 & 57.4 \\
\hline & 5 & 23 & 42.6 & 100. \\
\hline
\end{tabular}

Source: survey data, April 2015 and IBM SPSS Version 20.

Scale: outright cash purchase, capital asset ownership and availability for company operation $=$ strongly agree 5, agree 4, undecided 3, disagree 2, strongly disagree 1 . Net profit and turnover (Revenue) performances $=$ outstanding 5 , very good 4 , good 3, fair 2, poor 1 . Maintenance cost $=$ very low 5 , low 4, average 3 , high 2 , very high 1 .

\section{Descriptive Statistics}

The descriptive statistics are shown in table 3. Investment in capital assets by outright cash purchase has a mean score of 3.2222 or $64.44 \%$ on a 5 point scale. In comparison, acquisition by other approaches e.g. leasing and hire purchase account for $35.56 \%$. This approach promptly confers ownership on the investor as represented by a mean score of 4.5556 or $91.11 \%$. Because of delays arising from delivery bottlenecks and documentations for leased equipments, capital assets acquired by outright cash purchase are readily available for company operations. Its average rating on a 5 
point scale is 4.0926 or $81.85 \%$. The mean score for net profit performance of the companies studied is 2.6667 or $53.33 \%$. Though, a little above average, performance of construction companies is not encouraging. Egan's (1998) report on "Rethinking Construction", showed serious concern on the low and unreliable rate of profitability of the construction industry, which was difficult to sustain healthy development.

Turnover performance on the average is 3.4630 or $69.26 \%$ which is an impressive result when compared with net profit performance. This is because turnover is free from overheads unlike net profit determination. The mean score for maintenance cost is 4.2593 or $85.19 \%$. From the scale, this approximates to a "very low" maintenance cost which arguably is associated with newly acquired capital assets. In other words, newly acquired capital assets attract low maintenance costs than the ones already in use.

Table 3. Descriptive Statistics

\begin{tabular}{llllr}
\hline & Minimum & Maximum & Mean & $\begin{array}{c}\text { Std } \\
\text { Deviation }\end{array}$ \\
\hline Outright cash purchase & 1 & 5 & 3.2222 & 1.36902 \\
Capital asset Ownership & 4 & 5 & 4.5556 & 0.50157 \\
Av. For company operation & 2 & 5 & 4.0926 & 0.99562 \\
Net profit performance & 2 & 4 & 2.6667 & 0.77703 \\
Turnover performance & 2 & 5 & 3.4630 & 0.86249 \\
Maintenance cost & 3 & 5 & 4.2593 & 0.73164 \\
\hline
\end{tabular}

Source: IBM SPSS Version 20. Scale: see table 2.

\subsection{Bivariate Analysis}

Table 4 presents the correlation analysis between net profit performance and outright cash purchase of capital assets. The coefficient of correlation is 0.479 indicating a moderately positive relationship between net profit performance and capital assets acquired through outright cash purchase. This relationship is significant at 0.01 level ( 2 - tailed). Alternatively, the level of confidence that the result is true is $99 \%$. From this analysis, the hypothesis that there is no significant relationship between capital assets acquired by outright cash purchase and net profit is rejected.

The coefficient of determination is $22.94 \%$. This indicates that utility of capital assets acquired outrightly by cash explains changes in net profit performance by $22.94 \%$. Other factors aside acquiring own capital assets account for changes in net profit performance by $77.06 \%$.

Table 4. Correlation Analysis between Net Profit Performance and Outright Cash Purchase of Capital Assets

\begin{tabular}{cccc}
\hline & & Outright Cash purchase & Net profit performance \\
\hline Outright cash Purchase & Pearson correlation & 1 & $0.479^{* *}$ \\
& sig. $(2-$ tailed $)$ & 54 & 0.000 \\
& $\mathrm{~N}$ & & 54 \\
Net profit Performance & Pearson correlation & $0.479^{* *}$ & 1 \\
& Sig. $(2-$ tailed $)$ & 0.000 & 54 \\
\hline
\end{tabular}

** Correlation is significant at the 0.01 level $(2-$ tailed $)$

Source: IBM SPSS Version 20.

\section{Discussion of Findings}

Findings indicate a preference for acquisition of own capital assets outrightly by cash as opposed to other alternatives such as leasing. This makes for quick mobilization to construction sites since the equipments are readily available in the company premises. Ability to own construction equipments constitute an overriding factor in the construction industry. This determines the level of service delivery and continuity in business. Results indicate complete (100\%) acceptance of this view by respondents.

Similarly, in terms of turnover performance, older equipments already in use are unlikely to be as efficient as newly acquired ones. A total of 45 respondents representing $83.33 \%$ rate turnover performance emanating from own newly acquired construction machines "very good" or 4 on a 5 point scale. As documented by Mitchell (1998), smart 
acquisition practices fuel company success. Though, overall net profit performance is slightly above average, this is akin to the industry as a result of competition, high cost of labour and materials (Gianotti, 2003:6). Maintenance cost is very low for newly acquired capital assets. This is advantageous as it facilitates quick recovery of equipment cost at the early stages.

The descriptive statistics indicate $64.44 \%$ acceptance of purchasing capital assets outrightly by cash. Prompt transfer of ownership arising from this approach of capital assets acquisition is rated $91.11 \%$. An interesting reason for owning capital assets through immediate acquisition by paying cash is its availability for company activities. Respondents accord to this view to the level of $81.85 \%$ on the average. Similarly, net profit performance, from findings is $53.33 \%$. This is a little above average; profitability performance from the body of knowledge for construction companies generally, is not encouraging. However, because turnover is not burdened with overheads, results indicate $69.26 \%$ for the companies sampled. Reduction in maintenance cost for capital assets acquired newly by outright cash purchase is $85.49 \%$. This provides leverage to investors and sets up the stage for quick recovery of equipment cost.

From the bivariate analysis, findings indicate a significantly moderate positive relationship between utilisation of capital assets acquired by outright cash purchase and net profit. This association is significant at 0.01 level $(2-$ tailed $)$, implying a confidence level of acceptance of results of $99 \%$. Based on the correlation coefficient of 0.479 , capital assets acquired outrightly by cash accounts for changes in net profit performance by $22.94 \%$. Other factors such as technical skill, level of patronage, reduction in material prices and labour; etc., assume the balance of $77.06 \%$ explanation of changes in net profit.

\section{Conclusion and Recommendations}

Own capital assets acquired by outright cash purchase improve performance of construction companies. Overriding factors in evaluating their performance level are immediate availability for prompt mobilization for construction activities and reduction in maintenance cost. Findings indicate a statistically significant moderate positive relationship between capital assets acquired by outright cash purchase and net profit. Companies in the construction sector should aim at investing in capital assets through outright cash purchase instead of hiring or leasing.

This study is significant as it provides literature on cash purchase dimension of investing in capital assets in the context of construction companies. Further research should focus on other approaches of financing equipment acquisition; for example, leasing or hire purchase in other sectors of the economy, such as transportation.

\section{References}

Alexander, D., \& Britton, A (1999).Financial Reporting, London, International Thompson Business Press.

Chan, J. K. W., Tam, C. M., \& Cheung, R. K. C. (2005). Construction firms at the cross - roads in Hong Kong: Going insolvency or seeking opportunity, Engineering Construction and Architectural Management, 12(2), 112.http://dx.doi.org/10.1108/09699980510584476.

Egan, J. (1998). Rethinking Construction: The Report of the construction Task Force, London, DETR.

Gianotti, G. G. (2003). Chairman's Statement, CAPPA and D'ALBERTO Plc, Annual Report and Accounts, 6.

Hinze, J., \& Ashton, W. B. (1979). Current equipment policies of utility contractors, Journal of the Construction Division, 105(C03), 225-37.

Kehinde, J. O., \& Mosaku, T. O. (2006). An Empirical study of the assets structure of building construction contractors in Nigeria, Engineering, Construction and Architectural Management, 13(6), 634-644. http://dx.doi.org/10.1108/09699980610712418.

Libby, R., Libby, P. A., \& Short, D. G. (2001).Financial Accounting, New York, McGraw - Hill Companies Inc.

Mitchell, Z.W. (1998). A statistical analysis of construction equipment repair cost using field data and the cumulative cost model, Dissertation. The Virgina Polytechnic Institute and State University, Polacksburg, VA.

Nwanyanwu, L. A. (2013). Hire purchase Strategy of physical capital Investment and Financial performance of Construction Companies: Illustrating from the Nigerian stock exchange, Mediterranean Journal of Social Sciences, 4(4), 453. http://dx.doi.org/10.5901/mjss.2013.v4n4p449.

Prasertrungrung, T., \& Hadikusumo, B. H. W. (2007). Heavy equipment management practices and problems in Thai highway contractors, Engineering Construction and ArchitecturalManagement, 14(3), 228.

http://dx.doi.org/10.1108/09699980710744881.

Schexnayder, C. J., \& Hancher, D. E. (1981).Contractor equipment management practices, Journal of the Construction Division, 107(C04), $619-626$.

Stewart, L. (2002). Buyers Jungle more rental and leasing, Construction equipment, 105, 44. 
Sutton. R. (2003). The price - only trap, Construction Equipment, 106(3), 9.

Tavakoli, A., Taye, E. D., \& Erktin, M. (1989). Equipment Policy of top 400 contractors: A survey, Journal of Construction Engineering and Management, 115(2), 317-329.

Wood, R., \& Ross, D.G. (2006). Environmental Social controls and capital Investments: Australian evidence, Accounting and finance, 46, 677-695. http://dx.doi.org/10.1111/j.1467-629x.2006.00180.x

Yeo, K.T., \& Ning, J. H. (2006). Managing Uncertainty in major equipment pronouncement in Engineering Projects, European Journal of Operational Research, 171(1), 123-134.

\section{(cc) EY}

This work is licensed under a Creative Commons Attribution 3.0 License. 